\title{
Moral and Material Decay of Education. Ineffectivity and counter productivity of most potent force for Human development.
}

\author{
Mr. J. K. Behera \\ Ganges Jute Private Limited, West Bengal (India)
}

\begin{abstract}
Observations by many many great personalities underscore the penultimate importance, the education commands in modulating human development which is direct index of national growth. But it has undergone artificialisation and metamorphosis in adhering to value system even though it enjoys global standard in its nature \& content. Devoid of ethics and value system (Which again is a general phenomenon and not specific to education system alone), almost all Indians armed with highest standard and quality education adroitly camouflage in plundering the national exchequer using the gifted abilities produdly as license to do so. Other pernicious and most debilitating aspect is avoidable and unthinkable emasculation of vernacular education system where majority of Indian kids have their education as a fundamental right enshrined in constitution. Most from these end as school dropout, a part with scholarly potential go on at best to qualify for job like Doctors, Engineers other Govt. \& private jobs with some meaning while others simply turn out to be unemployable youth, running from post to pillar in search of Non-existing jobs, frustrated at miserable failure in interviews simply go on to add to social hooliganism which ultimately is objective the education to eradicate. In my accompanying article, I will attempt with comprehensive argument both moral and material decay of education and with free for all no holds bar democratic views, liberty with its need \& greed based utility, it is seriously ponderable to even imagine restoration of both moral and material standard of education.
\end{abstract}

Keyword: Penultimate, artificialisation, provision, debilitating, enshrined, eradicate \& restoration.

\section{Introduction:}

When asked about how much educated men were superior to those uneducated, great philosopher Aristotle answered "As much as living are to dead" Diogenes laitius.

"The essence of education lies in drawing out the best in you. Earning money can never be the purpose of education. Acquiring good qualities is the only aim of Education". Mahatma Gandhi.

"Few things are certain to be uncertain. Native ability without education is like a tree without fruit" - Theodore Roosevelt.

"Essence of Education is the education of the body" - Benjamin Disraeli.

"Learning is a treasure that will follow its owner every where" - Chinese Proverb.

The given introduction as a follow up to the abstract emphasizes in absolute sense \& terms the eternal and heavenly value the true education with its nobility carries.

As a concerned Indian citizen, I was visibly shaken with suicide of Anil Meena of AIIMS for his failure to cope up with English medium instructions and some details are given which I wrote during that period.

\section{Aiims Suicide Pointer To Plight Of Poor Students}

Boldly mentioned in the Indian English News paper "The Telegraph" dated 6 th February 2012 at page no. 6 pertaining to suicide of $1^{\text {st }}$ year AIIMS (All India Institute of Medical Science) Student Anil Meena, 22 Years Young student from rural Rajasthan tribal in failing to cope up with English Instructions since he hailed from vernacular School highlights a monstrous shadow on national Educational system which suffers from a very mighty siege from within capable of delivering death blow. Most unfortunate, I am writing this article on $7^{\text {th }}$ February and believe by this time artificially administered disaster must have caught attention, sleepant imagination of all concerned authorities and drove them to sit together, take stock of situation and would have already undertaken a overdrive aimed at immediate damage control and proper action plan for its speedy rationalization in line with imperatives and requirement.

I am not sure, how many concerned citizens have cared to go through its full text, realized its ramification leave alone contemplating correctives to restore its phase of vibrance and Glory. This simply brings to focus with highest visibility, the gross callousness, indifference, apapthy \& might be deliberate ignorance to such a noble cause like Education.

As a very seriously concerned citizen in this issue since demolition of English at elementary level, I had written an article entitled. "State Of English, Sharp Decline In Standard Of English Sounds Death Knell". 
Some times in 2007. I feel dutybound in event of the most unfortunate and surly unavoidable suicide at AIIMS on last Sunday to get it printed so that my submission which is a fervent, formidable, loading and leading plea must not go unheard in a democratic country where we have been granted "Right to Education" that must be implemented in absolute letter \& sprit. Simultaneously I believe, with such unfortunate incidence the ultimate alarm bell has already rung, all concerned must rise across all divides, formulate plans and take pain to implement these which will bring the country back from unthinkably precarious direction it is heading.

\section{State Of English, Sharp Decline In Standard Of English Sounds Death Knell}

Mad rush of anxious parents and guardians to find a seat for their ward in an elite English medium school and vernacular state owned educational institutions occurring to their minds as sheer desert is a very much alarming, dangerous, and detrimental portent fraught with serious consequence .such an abnormal situation has taken place not because of modern day high ambitions harbored by the parents, but because of abysmal decline in standard of English in state owned institutions thanks to the perilous educational reform designed by ox-bridge elites and our own civil authorities might be in their absolute senses to subvert these bodies from ultimate guarenteer of effective literacy to practically community hall where wards from underprivileged class cluster together to head nowhere.

My basic argument is, were the curriculum for these state owned institutions properly structured to accommodate English from elementary stage in appropriate manner, entailing them to learn this majestic language in desired proportion, these bodies, as on date would be continuing to produce composite students matching in all scholastic measures to their counter parts coming from elite English schools.

Let's move to more excruciating details. The state owned institutions function under ministry of education, buildings and other infrastructures are developed and maintained by the state, qualified teachers are selected through well defined recruitment system, their payments are commensurate with definite grade and scale designed to earn their effective performance in the job. Tuition fees, development fees and other charges in these bodies are nominal on account of being heavily subsidized with objective of spreading quality education to the door step of the poor at behest of the state exchequer. This is a state owned ingenious model which if nurtured properly will regain the glory of producing potential civil servants, doctors, engineers and well equipped civilians those can effectively participate and contribute to over all national growth. As of now, on account of ill devised curriculum and lack of care, the system being maintained by national exchequer is producing very ill-equipped students, absolutely poor in English knowledge much required for any meaningful higher education, negligible of them finding way to higher strata, others move to state owned institutions of higher learning with vernacular language as medium of instruction and come out as graduates and post graduates unsuitable for any meaningful job.

On the other hand, the mad rush to English medium schools by the parents and guardians to admit their wards is unprecedented and has resulted in mushrooming of these schools. These institutions charge heavy tuition, development fees and sundry other charges which would be many many times more than the expenses in state owned institutions. Further more, these bodies pay their teachers inadequately. How on earth are they believed to deliver excellence. The worst part of the contrast is that the expenses are clearly unaffordable by the middle class, they are to forgo other financial obligations to meet the ward's expenses as he/she is studying in coveted English school and all the agonies of parents are outweighed at their pride to have put their ward in appropriate place of learning.

The guardian thus remains, if need be, semi clad, under fed or blatantly resort to dishonest means in making money to meet the artificial demand made on him by the precarious system. The wards nurtured in a system of artificial luxury, it is very difficult to believe, will acclimatize themselves to socio-economic realities around them and if they fail to do so which many are doing, it is not they who are to be found fault with, it is the system at large which has to own up the responsibility for this disastrous episode.

Will we continue to malfunction in this way or gather nerve and verve to restructure, reorient and revamp the state owned model to suit to the present day needs. Things have come to such a sorry pass that when U.P governor advised students of Sampoornannd Sanskrit University in Course Of his convocation address on $9^{\text {th }} \mathrm{Feb}$. 2007 to learn English in addition to Sanskrit to expand the horizon of their knowledge and fulfill aspirations to make multi figure earning and foreign trips, he instead of being appreciated and hence duly respected, was pelted stones, hurled abuses, forced to cut short his speech, shouted to go back and most shockingly letters to the editor in news papers went on to lambaste the governors' approach, his colonial hangover and so on.

Can education which is supposed to act as a cornerstone and lifeblood for overall development in society have its due strength in present dispensation? The disintegration as elaborated above is proliferating in unbridled manner and if the rot has to be arrested before it is too late, it is now that a heavy knock has to be administered on heads of our elite denizens sitting on their cushy wheel chair in air conditioned compartment at state or national head quarters and loading the national policy on education to drive the nation to bullock cart Age to shake them off 
their mental stupor and see the light outside. This is a stupendous job and correctional programme has to be under taken right from now onwards in case we seriously want the change for betterment.

Ensuring sound educational system catering to needs of the nation, effectively rebuff its artificialisation is probably greatest investment any nation and for that matter India in particular can conceive of making. For this, political will has to be generated at the beginning and let's believe that our political class will not fail in their duty in realizing the gravity and making a prompt beginning.

American president Theodore Roosevelt's observation in the introductory part, "Few things are certain to be uncertain. Native ability without education is like a tree without fruit" is very much pertinent in this context.

\section{Moral Decay Of Education}

After having dealt with unfortunately administered material decay in education intended to keep the pervasive section fully subservient to elite class having had their education in oasis called elite Schools surrounded by vast $\&$ sprawling desert left for timid millions to inhabit and sustain themselves in given circumstances.

As argued by Mahatma Gandhi "Earning money can never be purpose of Education. Acquiring good qualities in the only aim of Education". This can be appropriately interpreted as human beings with proper education will more \& more dedicate themselves to development of nation in their capacity as its eyes and ears and earning sufficient to maintain themselves in standard commensurate with their position will be their rightful entitlement and nation addresses the issue with all due respect.

There is a saying "One who acquires knowledge but does not practice it as one who ploughs but does not sow" by Saadi. Drawing an analogy, it can be argued that the elite \& educated mass who have acquired scholarly material knowledge but suffer from moral bankruptcy engage themselves in their obligatory activities with strong $\&$ unventurable limit imposed by self and sectarian interest. This surely and effectively hinders national growth, leads to series of grossly irrational compromises and leaves behind a trail blazing effect with disastrous consequences.

"Management is efficiency in climbing ladder of success, leadership determines whether the ladder is leaning against right wall" - Stephen R. Covey. Exactly same is the case with education. A properly \& scholarly educated individual depending on his ideological inclination can be a patriot - a capacity in which he will make immense purposeful contribution to society, can be a money making mortal human being \& in that capacity for him money will set agenda for individual, societies \& nation and while steering his activities for making money, he will comfortably \& conveniently be completely oblivious of the harm he has caused to society \& how immorally he has failed to his duty when need \& greed has blinded him.

According to Jhon.W. Gardner - "Mastery is not something that strikes in an instant, like a thunder bolt but gathering power that moves steadily through time like weather".

Martin Luther King has said - "Everybody can be great, because everybody can serve. You do not have to have a college degree to serve. You do not have to have to make your subject \& your verb agree to serve. You do not have to know the $2^{\text {nd }}$ theory of thermodynamics in physics to serve. You only need a heart full of grace. A soul generated by love".

These immortal quotes are not only of eternal relevance and can be practiced in all ages, all times and all places over mother earth for benefit of mankind. When we talk of welfare of mankind we must be aware that our artificial modal has forced at least $75 \%$ of population to remain in poor income bracket of Rs. 25 to Rs. 30 Per day and hence in this era of sky rocketing prices of all commodities, these millions with hardly any purchasing power are left to themselves with unspeakable misery when members of political class are platituding tall promises with no matching activities, elite members in charge of administration are busy plundering the state exchequer and employing god gifted brain to offer highly acclaimed explanation for losses.

It is pity that character / honesty in present society is seen either as incapability or as lack of ability to make money. Instead of a superhuman conduct, it is visualized as ineptitude and inefficiency. A heart full of grace \& soul generated by love fall in the domain inhabited by honest people who could not take recourse to dishonesty. What can be more bizarre \& sorry figure to portray the eternal qualities like good conduct and honesty in ? Further philosopher Aristotle has said, "All those who have mediated on art of governing man-kind have been convinced that fate of empire depends on youth education".

While observing this, Aristotle must have both moral \& material dimension of education in his mind. Had he been around us at this critical moment, he certainly would have modulated his saying in line with on going Socio-economic \& cultural phase.

The deliberation over moral decay can be continued endlessly, but the fact of the matter is . in our democratic dispensation, is it going to make those in charge of governance even to think leave alone acting on it. May be the saying "Feelings turn riot when voice of reason seldom Works" is operating with fullest force in present tims but the do gooders must keep themselves shouting with ultimate faith in being heard some day or other. 
It might not be out of place to quote an emiment Journalist writing, - Brilliant lawyers make star appearance with astronical charges to bail out the top notch criminals While phenomenon is nothing new and is continuing since time immemorial, the law as one of the noblest profession being employed by its much respected practitioners for counter productive and even antihuman purpose sends a severe shiver down the spine. Having lost parliamentary elections, an outstading lawyer and brilliant parliamentarian, when questioned as to how he would maintain himself in absence of Govt. privileges, benefits etc, in stead of responding modestly, strongly retorted back that ruling party was full of criminals and hence his hands were full \& not an iota of thinking for monetary aspect. Having said this I must dutifully turn to the light at end of the tunnel and must recall when an eve of Bhopal Gas tragedy in Union carbide plant in 1984 , the parent organization M/s UCC ( Union Carbide Corporation ) came to late legal luminary Mr N A Palkivala with astronomical offer of commission from sales proceeds of ICPD ( International Consumer Product Division ), Hongkong based lucrative UCC outfit ( The move of selling ICPD was to exhaust Company's wealth so that during much dreaded court verdict UCC can show it has nothing / niggardly assets / wealth to meet the adjudicated compensation), the great partriot had simply said that for him dignity of mother India was far more important than astronomical money being offered and termed the case as transatlantic ambulance chasing. As a living multicolored ingenious personality he was pride of mother India and continuous to remain too even in his death. Ultimate patriotism bereft of self - interest and with passionate love for democracy \& public service are the greatest values which death even can not snatch away.

However it is no surprise that the same UCC case was immediately taken up by another Mumbai based famous legal baron and plight of Bhopal Gas Victims is strikingly visible to all of us at the moment.

My contention, this shrill, feeble and very isolated voice and act of ultimate sanity is hardly finding any taker. Complete material mindedness encompassing unending need $\&$ greed having forcefully become order of the day, Socio - economic, political \& every other single issue is being defined \& determined accordingly. Formalities $\&$ official procedures provide much needed \& camouflaged surface dressing. While giving up optimism altogether, I do not stand out as a pessimist either and retain firm faith in epic Bhagbat Gita that God will incarnate himself to save Mother India from becoming Precipice.

V.

\section{Conclusion}

All our foregoing discussion on State of Education epitomizes single penultimate conclusion - Outright denial of right to Education in its truest spirit as enshrined in article 45 of our constitution. In absence of a student, how are we going to have "a student of today is a citizen of tomorrow".

Moral decay of Education and for that matter of all other human values have wrought incalculable \& avoidable havoc on mankind. But material decay particularly related to abolition of English in vernacular Schools, mushrooming English medium schools producing socially artificial students, proliferation of centers higher Educations like Engineering, management, healthcare etc, with very very poor infrastructure churning out grossly incompetent graduates and hardly qualifying for meaningful placements is seriously worrisome.

Maintenance of official documents in different Indian States in their vernal languages is compounding the misery \& adding owes to the injury. This is a venal approach by political class in the name of adopting Modern Indian Language and driving back the country to bullock cart age when the nation commands $3^{\text {rd }}$ Largest Scientific base \& numerous Indian talents in humanities like History, Economic, Literature etc \& more often than not bearding the Global Lions in their own den. Union HRD Minister Mr.Kapil Sibal's observations on lesser utility of those with BA or BA (Hons.) degree in participation of National Economic Growth (English Newspaper Telegraph dated $11^{\text {th }}$ September 2012) is much related to material decay of the system.

Much that arguments may come contrary, ambivalent including even further clarification by eminent lawyer turned Minister; the observation made is undeniable \& quality of Education at elementary level \& that in normal Institution is in urgent need of being brought to standard.

Artificial objective of elite class administering the system and devising it to make the timid millions their subservient must have to be properly addressed by the authorities \& I emphatically argue that there can be no hindrance in achieving this. My single question why stoic silence by Govt. authorities to this issue deserving to be set right without any lapse of time.

Let the democratic Govt. be finally reminded that it is a Govt. "Of the people, by the people \& for the people" concludingly, I place the loading \& leading argument that welfare of the nation consisting of welfare of its citizen lies in properly structured, truly meaningful educational system and empowering the society through spirited implementation of right to education. No nation \& for that matter India can \& must not gloss over it and must immediately act upon effectively even though it is too late. In my article I have argued some aspects only \& vast section remain untouched due to time \& space constraint. But for all well meaning citizens, this is all well understood \& hence points said will surely accompany with itself many relevant issues unsaid.

\section{Reference}

[1] Article in the English News paper the Telegraph dated $6^{\text {th }}$ February 2012 \& $11^{\text {th }}$ September 2012

[2] Quotes of Greek Philosopher Aristotle, Diogenes Laitius, Mahatma Gandhi, American President Theodore Roosevelt, Benjamin Disraeli, Chinese Proverbs, Saadi, Stephen.R.Coy, John.W.Gardner, Martin Luther King.

[ The author is the The General Manger, Ganges Jute Private Limited , can be contacted with mobile No +919836572732 and Email Id jkbehera59@gmail.com. The views expressed are of the author himself and are in no way related to the organisation he works for ] 